\title{
Intratumoral chemotherapy in an integumentary squamous cell carcinoma in a cockatiel (Nymphicus hollandicus)
}

\author{
Intratumorale chemotherapie van een plaveicelcarcinoom van de huid \\ bij een valkparkiet (Nymphicus hollandicus)
}

\author{
${ }^{1}$ N. Van Hecke, ${ }^{1}$ A. Martel, ${ }^{1}$ A. Garmyn, ${ }^{3}$ I. Van de Maele, ${ }^{1}$ T. Hellebuyck, ${ }^{2}$ S. Croubels, \\ ${ }^{1} R$. Ducatelle, ${ }^{1,2} \mathrm{G}$. Antonissen \\ ${ }^{1}$ Department of Pathology, Bacteriology and Avian Diseases, Faculty of Veterinary Medicine, \\ Ghent University, Salisburylaan 133, 9820 Merelbeke, Belgium \\ ${ }^{2}$ Department of Pharmacology, Toxicology and Biochemistry, Faculty of Veterinary Medicine, \\ Ghent University, Salisburylaan 133, 9820 Merelbeke, Belgium \\ ${ }^{3}$ Small Animal Department, Faculty of Veterinary Medicine, Ghent University, Salisburylaan 133, \\ 9820 Merelbeke, Belgium
}

Gunther.Antonissen@UGent.be

A

BSTRACT

An eight-year-old, female cockatiel (Nymphicus hollandicus) was presented with anorexia, lethargy, a mass at the lower side of the wing and discoloration of the feathers. Physical examination showed an ulcerated nodular integumentary lesion of approximately $4 \mathrm{~cm}^{3}$ ventromedial on the wing at the side of the propatagium and the humerus. Lateral and ventrodorsal radiographs revealed only hepatomegaly. After a stabilization period, surgical excision of the tumor was performed. Based on histopathological evaluation and bacterial culture of the surgically removed tissue, the lesion was typed as an integumentary squamous cell carcinoma with secondary bacterial infection (Corynebacterium $s p$ ). Four weeks postoperative, the tumor had recurred. Chemotherapeutic treatment was started with intratumoral carboplatin $\left(1.5 \mathrm{mg} / \mathrm{cm}^{3}\right)$ once a week. Because of further tumor growth after the second administration of carboplatin, resection of the mass was performed before the next infiltration. However, the bird died during anesthesia. Despite increase in tumor size, histopathological and immunohistochemical evaluations showed degeneration of the tumor with intercellular edema and vacuolization of the tumor cells, presumably resulting from carboplatin administration. More research is needed to investigate the efficacy and safety of the intratumoral administration of carboplatin as a treatment option in birds with integumentary squamous cell carcinoma.

\section{SAMENVATTING}

Een acht jaar oude, vrouwelijke valkparkiet (Nymphicus hollandicus) werd aangeboden met klachten van anorexie, lethargie, een massa onderaan de vleugel en verkleuring van het vederkleed. Het lichamelijk onderzoek toonde een ulceratief nodulair letsel van de huid van ongeveer $4 \mathrm{~cm}^{3}$, ventromediaal op de vleugel ter hoogte van het propatagium en de humerus. Op een laterale en ventrodorsale radiografie was er als enige afwijking hepatomegalie zichtbaar.

$\mathrm{Na}$ een stabilisatieperiode werd er een chirurgische excisie van de tumor uitgevoerd. Uit het histopathologisch onderzoek en de bacteriële cultuur van de chirurgisch verwijderde massa bleek de laesie een integumentaal plaveicelcarcinoom te zijn, secundair bacterieel geïnfecteerd met Corynebacterium $s p$. Vier weken postoperatief was de tumor gerecidiveerd. Een behandeling met chemotherapie werd opgestart, waarbij éénmaal per week carboplatine intratumoraal $\left(1,5 \mathrm{mg} / \mathrm{cm}^{3}\right)$ werd toegediend. Omwille van de verdere tumorgroei na de tweede toediening van carboplatine werd de massa gereseceerd voordat de volgende toediening van carboplatine plaatsvond. De vogel overleed echter tijdens de anesthesie. Histopathologisch en immunohistochemisch onderzoek toonde degeneratie van de tumor met intercellulair oedeem en vacuolisatie van de tumorcellen aan, ondanks de toenemende tumorgrootte. Vermoedelijk was dit het resultaat van de carboplatinetoediening. Verder onderzoek is nodig om de werkzaamheid en veiligheid van de intratumorale toediening van carboplatine te bestuderen als behandelingsoptie bij vogels met een plaveicelcarcinoom van de huid. 


\section{INTRODUCTION}

Life expectancy of companion birds is increasing due to improved husbandry, nutrition and veterinary care. Consequently, a growing number of degenerative and neoplastic diseases in birds are diagnosed and treated by veterinarians (Robat et al., 2017). Neoplastic processes are more frequently diagnosed in cage birds than in aviaries or in wild birds (Siegfried, 1982). Among psittaciformes, the budgerigar (Melopsittacus undulatus) is most frequently diagnosed with neoplasia (Ratcliff, 1933). A private exotic species pathology service showed that of the geriatric population, $66.7 \%$ of budgerigars submitted to the clinic showed neoplastic disease; in geriatric cockatiels (Nymphicus hollandicus) this was $49.6 \%$ while in other psitacciformes species only one third had a neoplastic process (Reavill and Dorrestein, 2010). Neoplastic processes of the skin are the most frequently diagnosed tumors in pet birds $(31.7 \%)$, followed by the urinary system $(25.1 \%)$ and the reproductive system (17.3\%) (Leach, 1992).

A squamous cell carcinoma (SCC) is a malignant neoplasia, which originates from the squamous epithelium of the skin or the proximal part of the gastrointestinal tract (Koski, 2002; Reavill, 2004; Klaphake et al., 2006). A SCC is histologically characterized by infiltrative nests and cords of moderately undifferentiated to poorly differentiated squamous cells, which frequently form so called 'keratin pearls', presenting as central cores of compressed and laminated keratin (Reavill, 2004). Of the pet birds diagnosed with a neoplastic process, $1.7 \%$ suffer from SCC (Malka et al., 2005). The bird species that are most commonly diagnosed with SCC are the cockatiel, the amazon parrot (Amazona spp.) and the budgerigar (Koski, 2002; Reavill, 2004; Klaphake et al., 2006). The predilection sites of SCCs in birds are the distal part of the wing, phalanx and uropygial gland (Koski, 2002; Lightfoot, 2010).

Multiple risk factors have been associated with the development of integumentary SCC in humans and animals (Klaphake et al., 2006). It is known in mammalian species that long-term exposure to ultraviolet (UV) radiation of poorly pigmented zones is a risk factor for the development of SCC (Meleo, 1997; Reavill, 2004; Klaphake et al., 2006; Abu et al., 2009). However, in birds, SCC mostly occur in skin regions, which are not exposed for a long period of time to sunlight (Reavill, 2004). In addition, chronic exposure to cigarette smoke, chronic skin disease, chronic feather picking, a species-specific poxvirus in young chickens, and other unknown factors have been documented as predisposing factors for the development of integumentary SCC in birds (Koski, 2002; Reavill, 2004; Klaphake et al., 2006).

As in mammals, the prevalence of metastasis of SCC in birds is low (Koski, 2002; Reavill, 2004; Malka et al., 2005; Klaphake et al., 2006; Abu et al., 2009;
Lightfoot, 2010). Metastasis of SCC in birds is mostly found in the lungs, the spleen, the cortex of bones and the liver (Abu et al., 2009). Although the tendency to metastasize is very low, the capacity of tumor invasion into the surrounding tissue is generally very high, which results in a guarded prognosis (Manucy et al., 1998; Koski, 2002; Reavill, 2004; Malka et al., 2005; Klaphake et al., 2006; Abu et al., 2009; Lightfoot, 2010). Additionally, severe necrosis caused by the fast growth of the tumor or related to treatment, especially chemotherapy and radiation, might worsen the prognosis because of an increased risk of developing septicemia following secondary infection (Klaphake et al. 2006; Lightfoot 2010). The prognosis is also negatively influenced by age and delayed diagnosis (Manucy et al., 1998; Klaphake et al., 2006).

The use of chemotherapeutics as a possible treatment strategy in avian oncology has been steadily increasing in recent years (Zehnder and Kent, 2011). Platinum-based antineoplastic agents are commonly used to treat integumentary neoplastic processes (Mo et al., 2014). However, defining the optimal treatment protocol for tumors in birds is still largely empirical. The treatment protocols used in birds have been extrapolated from other companion animals, such as dogs and cats or humans (Graham et al., 2004). Antonissen et al. (2015) demonstrated a correlation between body weight (BW) and carboplatin elimination half-life $\left(\mathrm{T}_{1 / 2 \mathrm{el}}\right)$ to allow allometric scaling of carboplatin in avian species. Cisplatin and carboplatin form reactive intracellular platinum complexes that bind to nucleophilic groups in the DNA, producing both inter- and intra-strand crosslinks that inhibit DNA replication, RNA transcription and protein synthesis, resulting in apoptosis (Mo et al., 2014). Carboplatin was developed to reduce the myelosuppression, nephrotoxicity and nausea associated with cisplatin, a firstgeneration platinum agent (Ito et al., 2013).

In this report, the first case of intratumoral administration of carboplatin in a SCC in a cockatiel is described.

\section{CASE}

An eight-year-old, female cockatiel was presented with anorexia, lethargy, discoloration of the feathers and a progressive, slow-growing mass at the ventral side of the left wing. The mass had been observed approximately two months before presentation. The owner observed that the tumor started bleeding after handling the bird. A few days prior to the moment of initial presentation, the bird showed polydipsia (PD). The bird was housed in an indoor cage together with another cockatiel and was fed a diet consisting primarily of seeds with additional bird-snacks and table scraps. Drinking water was supplemented with a mixture of vitamins (Multi-Vit, Beaphar, Poperinge, Belgium). 
On physical examination, the bird showed a poor general and body condition and weighed $90 \mathrm{~g}$. The skin was less densely feathered and the area of the left eye, ear and dorsal side of the wing were bald. In contrast to the original color of the feathers (white to light yellow), all feathers had been intense yellow since one month. An ulcerated nodular integumentary lesion of approximately $4 \mathrm{~cm}^{3}$ was observed, which was located ventromedial on the left wing at the side of the propatagium and the humerus (Figure 1). Cytological examination after a hemacolor staining of a fine-needle aspiration of the nodule revealed multiple epithelial cells with irregular size and several nucleoli per cell, which suggested a neoplastic process. Lateral and ventrodorsal radiographs revealed hepatomegaly, but no signs of metastases. Further diagnostic evaluation, including blood hematology and biochemistry, liver biopsy and PCR test for Chlamydia psittaci were declined by the owner because of financial constraints. In summary, anamnesis and clinical examination suggested an integumentary neoplasia and chronic liver failure. The differential diagnosis of the liver disease was septicemia, hypovitaminosis A, neoplasia and degenerative liver disease.

During a period of seven days, the bird was stabilized supporting liver function by oral administration of milk thistle $(75 \mathrm{mg} / \mathrm{kg}$ BW, PO, BID, Elusanes Mariadistel, Pierre Fabre Santé Benelux, Belgium), which is a natural herb that has antioxidant and antiinflammatory properties and B-chol, a mixture of sulphuric amino acids, biotin, sorbitol and vitamin B12, (1ml / $100 \mathrm{ml}$ drinking water) (Oropharma, Belgium) to stimulate the excretion of bile. Besides, enrofloxacine $(20 \mathrm{mg} / \mathrm{kg}$ BW, PO, BID, Baytril, Bayer Animal Health, Belgium) was administered, since the diagnostic tests could not exclude septicemia. Surgical intervention was performed to remove the tumor. Induction was achieved with $5 \%$ isoflurane in $1.5 \mathrm{~L} / \mathrm{min}$ oxygen administered via mask. After induction, anesthesia was maintained with $2 \%$ isoflurane in $1.5 \mathrm{~L} /$ min oxygen. The mass was surgically removed at the

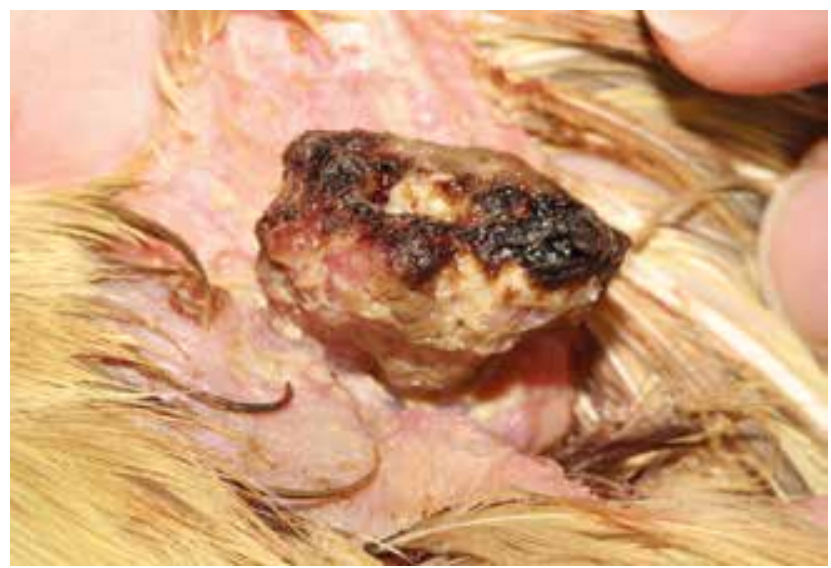

Figure 1. Integumentary squamous cell carcinoma in an eight-year-old, female cockatiel (Nymphicus hollandicus) before chemotherapy. base of the tumor and sutured with vicryl 4.0 (Ethicon, Sommerville, NJ, USA). Due to the location of the mass, it was impossible to include a surgical margin around the tumor. Wing amputation was declined by the owner. The mass was fixed in a 4\%-neutralbuffered formalin solution and processed afterwards according to the conventional methods for hematoxylin and eosin (HE) staining. At the end of the surgery, a swab for bacterial culture was taken from the surgical field at the side where the base of the tumor was resected.

Histopathological evaluation of sections of the surgically removed tissue showed a vaguely defined mass consisting of strains and clumps of large, polygonal cells with clearly defined cytoplasm and large, round and pale nuclei with fine fibrous chromatine and one to two large, eosinophylic nucleoli. Furthermore, a moderate anisokaryosis and mild anisocytosis, and an occasional formation of syncytial cells were observed, intermixed with a moderate amount of fibrovascular stroma. At multiple sites, large pearls of keratin were observed (Figure 2). The tissue was mildly infiltrated with heterophils. The mitotic index was three mitotic figures per high-power field (HPF). Based on histopathological examination, the tumor was typed as an integumentary SCC. The superficial part of the tumor was ulcerated and infiltrated with bacteria. Bacterial culture of the wound revealed contamination with Corynebacterium sp., and based on the antimicrobial drug susceptibility profile, the postoperative treatment consisted of amoxicillin/clavulanic acid (125 mg/kg BW, PO, BID, Noroclav, Norbrook Laboratories Limited, Northern Ireland) during two weeks, B-chol and milk thistle.

Sixteen days postoperative, the general clinical condition of the bird was improving. The animal was more alert, showed increased preening behavior and the PD had disappeared. However, the surgical wound did not heal, suggesting either a bacterial infection or a reoccurrence of the SCC. Bacterial and mycological examination of the wound was negative.

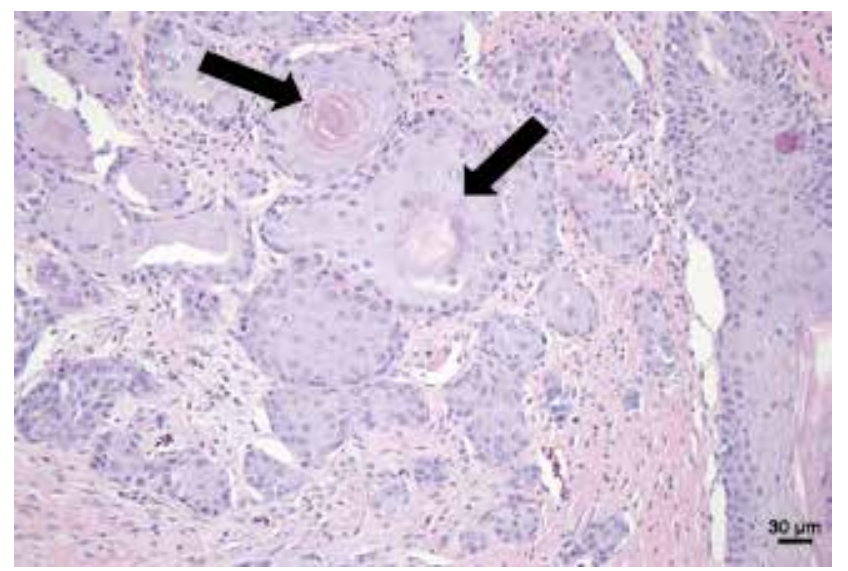

Figure 2. Histopathological examination of squamous cell carcinoma prior to carboplatin administration: strands of tumor cells surrounding keratin pearls (black arrows). 


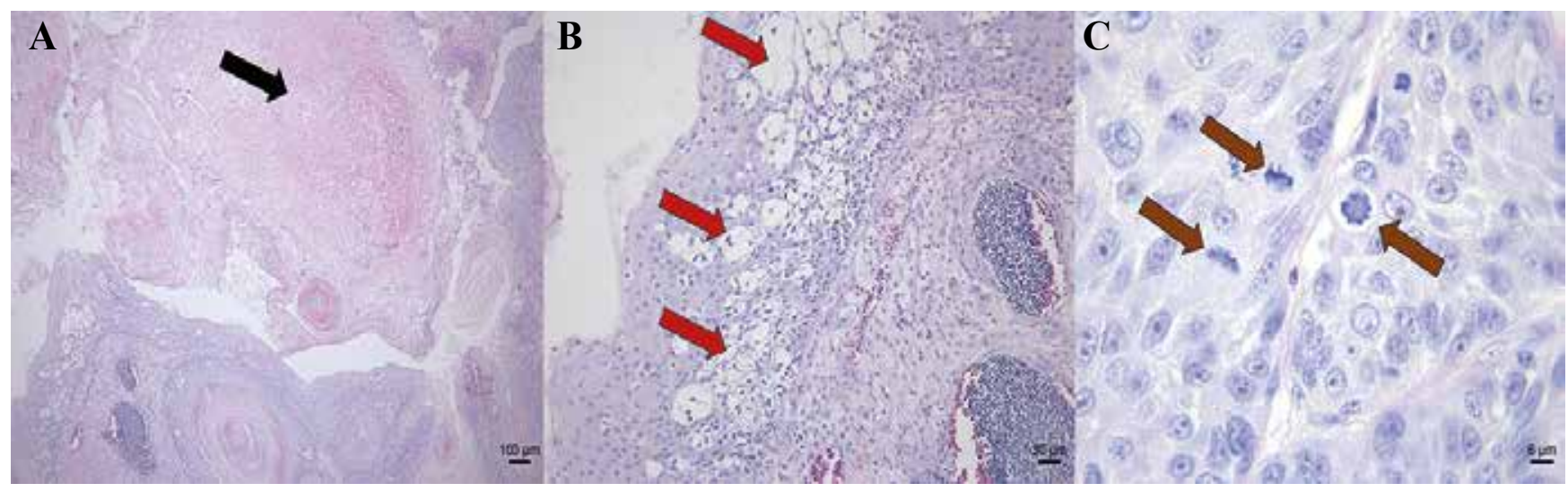

Figure 3. Histopathological examination of squamous cell carcinoma at necropsy (following carboplatin treatment) showed A. tumor necrosis (black arrows), B. vacuolar degeneration (red arrows) and C. mitotic catastrophe (brown arrows).

Four weeks postoperative, the clinical condition of the bird was improved, the bodyweight increased (95 g), and the bird started moulting, characterized by the appearance of the normal white to light yellow feathers. The tumor however, had reoccurred at the side of the non-healing surgical wound. Blood hematology and biochemistry showed no aberrant values apart from an increased creatine kinase level of 961 U/L (reference value: 30-245 U/L, Carpenter, 2012), which indicates leakage of the enzyme from muscle cells, often as a result of inflammation or trauma. Intratumoral administration of carboplatin $\left(1.5 \mathrm{mg} / \mathrm{cm}^{3}\right)$ was started on a weekly basis. Carboplatin was administered during general inhalation anesthesia with isoflurane as previously described, and analgesia was provided using buprenorphine (0.1 $\mathrm{mg} / \mathrm{kg}$ BW IM). Carboplatin (Carboplatin Hospira Onco-Tain ${ }^{\circledR}$ injection $10 \mathrm{mg} / \mathrm{ml}$, Hospira, Belgium) was mixed 1:1 with sterile filtered sesame oil (Sigma-Aldrich, Belgium). The length (L), width (W) and height $(\mathrm{H})$ of the tumor were measured and the volume was calculated at $0.7 \mathrm{~cm}^{3}$ based on the formula " $\mathrm{L} \times \mathrm{W} \times \mathrm{H} \times \mathrm{Pi} / 6$ ". Because the carboplatin solution would only diffuse 2-3 mm, a grid was created on the tumor with injection points being spaced every $5 \mathrm{~mm}$, resulting in an overlap of the radius from adjacent points. For the administered dosage of $1.5 \mathrm{mg} / \mathrm{cm}^{3}$, this resulted in 0.02 $\mathrm{ml}$ being injected per infiltration site. One week after the initial carboplatin administration, the tumor was still growing and measured $1.56 \mathrm{~cm}^{3}$. A second intratumoral administration of carboplatin was done following the same protocol. Because of further tumor progression after the second administration of carboplatin, the decision was made to surgically resect the mass before the next infiltration chemotherapy. However, the bird died during general anesthesia prior to the start of this procedure.

A complete post-mortem examination of the cockatiel was performed. The SCC measured $1.86 \mathrm{~cm}^{3}$. The superficial part of the tumor was black and showed an ulcerative appearance. Furthermore, macroscopic examination at necropsy revealed mild atrophy of pecto- ral muscles, congestion of lungs and liver and hepatomegaly. Histopathological examination of the tumor showed a similar image as the initial mass. However, large zones of necrosis (Figure 3A) and bacterial colonization were seen in the tumor, and there was infiltration with a limited number of lymphocytes and plasma cells. At different locations in the tumor, there was vacuolar to hydropic degeneration of the neoplastic cells next to a distinct intercellular edema (Figure 3B). The mitotic index was higher than in the sections of the initially removed mass (8 mitotic figures per $\mathrm{HPF}$ ), but these were mainly atypical mitotic figures. This form of cell death is termed mitotic catastrophe (Figure 3C). Immunohistochemistry of the tumor was performed both on sections of the surgically removed tumor before intratumoral carboplatin injection, and on sections of the tumor at necropsy. Clumps of cytokeratin positive cells were seen in the tumor before chemotherapy but also during the treatment. An Ecadherine immunohistochemistry test suggested the absence of apoptosis of the neoplastic cells, indicating vacuolar to hydropic degeneration of cells. Histology of the other tissues showed no metastatic disease but the lungs to be diffusely congested and containing several small aggregations of melanocytes. Multifocal epithelization of the Bowman capsule were observed in the kidney. The liver was diffusely congested. A multifocal, mild vacuolization of the cytoplasm of the hepatocytes was observed. Additionally, the hepatocytes contained a brown granular pigment and no signs of metastasis were found. Multifocal nests of heterophils and hemosiderin-loaded macrophages were present in the liver parenchyma. The white pulp of the spleen consisted mostly of lymphoblasts and macrophages. The red pulp was relatively anemic and contained many macrophages, some of them were hemosiderin-loaded.

To support further diagnostics of the underlying chronic liver failure, additional tests were performed. The PCR test for chlamydia of liver tissue, which was stored at $-20^{\circ} \mathrm{C}$ after necropsy, was negative. To test hypovitaminosis $\mathrm{A}$, the level of vitamin A was deter- 
mined by high performance liquid chromatography (HPLC) in the liver tissue (Medilab, Ghent, Belgium), and was considered to be normal (405.9 $\mu \mathrm{g} / \mathrm{g}$ tissue, Friedman et al., 1991).

\section{DISCUSSION}

This case report shows an integumentary SCC in a cockatiel treated with intratumoral administration of carboplatin following surgical excision. Surgical excision of a SCC is considered to be the first-choice therapy (Koski, 2002; Filippich, 2004; Reavill, 2004; Malka et al., 2005; Klaphake et al., 2006). Taking into account the aggressive local invasion of a SCC, a surgical margin of $1 \mathrm{~cm}$ is suggested in order to achieve a complete excision (Lightfoot, 2010). Similar as in this case, neoplastic processes in birds are often presented in an advanced stage; therefore, complete tumor excision is not always possible. Tumor localization on the wing made complete excision impossible in this case. Wing amputation could have been considered as an alternative treatment approach (Filippich, 2004). However, this was declined by the owner. Since birds are highly inclined to use flight as means of locomotion, wing amputation might negatively affect animal welfare (Harris, 1997). Another disadvantage of wing amputation might be the occurrence of keel trauma in birds attempting to fly and hitting the floor or other surfaces (Zhang et al., 2011). In a survey of 85 cases of SCC in birds, Zehnder et al. (2014) found an odds ratio of 7.48 for complete or partial response in patients that had complete surgical excision. Complete surgical excision of a SCC yields the best hope for cure.

Since complete tumor excision is not always possible, a combination of different treatment strategies should be taken into account to improve treatment outcome (Manucy et al., 1998; Filippich, 2004; Graham et al., 2004; Mehler and Bennett, 2004; Mauldin and Shiomitsu, 2005; Lightfoot, 2010). Chemotherapy may be used in addition to surgical excision, with or without radiation therapy or cryosurgery (Meleo, 1997; Filippich, 2004; Graham et al., 2004; Filippich and Charles, 2004; Ferrel et al., 2006). Cisplatin, carboplatin and 5-fluorouracil have been used empirically for the treatment of SCCs in birds (Filippich, 2004). Three cases of oral SCC and one case of a submandibular SCC in psittacine birds showed partial remission after intratumoral administration of cisplatin and a combination with cryotherapy. The species involved were an African grey parrot (Psittacus erithacus), an eclectus parrot (Eclectus roratus), a green wing macaw (Ara chloroptera) and a Wagler's conure (Aratinga wagleri) (Lightfoot, 2010). Manucy et al. (1998) reported the unsuccessful treatment of concurrent usage of a SCC of the mandibular beak in a Buffon's macaw (Ara ambigua) with the combination of Cobalt-60 radiation therapy and intratumoral cisplatin administration. In the present case, carboplatin was selected instead of cisplatin, taking into account the lower toxicity of carboplatin compared to cisplatin, with a similar mode of action and efficacy as observed in human medicine (Ito et al., 2013; Dilruba and Kalayda, 2016). However, carboplatin is less potent than cisplatin; therefore, depending on the type of cancer, the dosage of carboplatin is usually four times higher than that of cisplatin to achieve similar effectiveness. This difference is related to the kinetics of the aquation reactions of cisplatin and carboplatin and their subsequent reactions with DNA (Knox et al., 1986). Taking into account the patient's suspected history of chronic liver disease and the risk of carboplatininduced hepatotoxicity in the present case, intratumoral chemotherapy was preferred over intravenous or intra-osseous administration (Manucy et al., 1998; Filippich, 2004; Kent, 2004; Vail and Thamm, 2005). It has been suggested that intratumoral administration of chemotherapy has the benefit to reach a higher drug concentration at the tumor site with less systemic side effects (Manucy et al., 1998; Filippich, 2004; Graham et al., 2004; Filippich and Charles, 2004). Due to their radiosensitization effect, simultaneous administration of cisplatin or carboplatin and radiation therapy might improve therapeutic success (Meleo, 1997; Manucy et al., 1998; Filippich, 2004; Graham et al., 2004; Filippich and Charles, 2004; Vail and Thamm, 2005). However, radiation therapy was not added to the cockatiel's treatment protocol because of financial constraints.

Carboplatin dosage was selected based on a study in cats with a SCC at the planum nasale, which were successfully treated with intratumoral carboplatin in purified sesame oil at a dosage of $1.5 \mathrm{mg} / \mathrm{cm}^{3}$ with an interval of ten to fourteen days between different administrations (Theon et al., 1996; Vail and Thamm, 2005). Chemotherapy in birds has not been widely used, and therefore, treatment protocols are mostly extrapolated from other animal species (Filippich, 2004; Kent, 2004; Filippich and Charles, 2004; Hahn, 2005). Mixing carboplatin with a collagen matrix or a water in sesame oil emulsion, which is more cost effective, prevents a fast diffusion of the drug out of the neoplastic tissue (Graham et al., 2004). Following intravenous or intra-osseous administration, carboplatin has longer persisting levels of free plasma platinum than cisplatin, due to a higher mean $T_{1 / 2 \mathrm{el}}$ of free plasma platinum in sulphur-crested cockatoos (Cacatua galerita) (Filippich et al., 2000; Filippich et al., 2004). For carboplatin, the mean $\mathrm{T}_{1 / 2 \mathrm{el}}$ of free plasma platinum counts $1.0 \pm 1.7$ hours and for cisplatin $0.413 \pm 0.122$ hours only. This difference in mean $T_{1 / 2 \mathrm{el}}$ is probably a result of a difference in body clearance between carboplatin $(5.5 \mathrm{~mL} / \mathrm{min} / \mathrm{kg} \mathrm{BW})$ and cisplatin $(11.7 \mathrm{~mL} / \mathrm{min} / \mathrm{kg} \mathrm{BW})$ (Filippich et al., 2000; Filippich et al., 2004). Recently, Antonissen et al. (2015) demonstrated by allometric scaling a clear correlation $\left(\mathrm{R}^{2}>0.97\right)$ between $\mathrm{BW}$ and the elimination half-life $\left(\mathrm{T}_{1 / 2 \mathrm{el}}\right)$ of carboplatin in different avian species, i.e. budgerigar, pigeons, ducks and chickens, 
expressed by the formula: $\mathrm{T}_{1 / 2 \mathrm{el}}$ carboplatin $=0.1147(\log$ value of $\mathrm{BW})^{0.3046}$. The highest platinum accumulation after carboplatin administration occurs in the kidneys and liver, and is comparable with the concentrations found after administration of cisplatin (Filippich et al., 2004; Filippich and Charles, 2004; Filippich et al., 2005). However, intratumoral platinum accumulation and the carboplatin elimination rate following intratumoral administration are unknown. Similarly to this case, an amazon parrot with a integumental SCC was treated with surgical debulking and intratumoral carboplatin at a dosage of $5 \mathrm{mg} / \mathrm{kg} \mathrm{BW}$ in a $10 \mathrm{mg} /$ $\mathrm{ml}$ water in sesame oil emulsion, with a temporary growth interruption of the SCC (Wilson et al., 2000).

No clinical signs of carboplatin toxicity were observed in this case. However, blood hematology and biochemistry were not evaluated after the administration of carboplatin. Filippich et al. (2005) observed anorexia and vomiting in cockatoos following to carboplatin administration at a dose of $5 \mathrm{mg} / \mathrm{kg} \mathrm{BW}$. Myelosuppression is a dose limiting side effect of carboplatin. However, this has only been described in avian cases where carboplatin was administered at multiple doses of 11.25-15 mg/kg BW (Filippich, 2004; Childs-Sanford et al., 2006). Nevertheless, histopathology of the spleen revealed that the red pulp was relatively anemic, but with many macrophages. In comparison to cisplatin, carboplatin has a less pronounced neurotoxicity and ototoxicity when used in human patients (Kelland, 2007; Thomas and Chatelut, 2007; Dilruba and Kalayda, 2016).

Despite the increase in tumor size, histopathological evaluation showed vacuolar to hydropic degeneration. The presence of mitotic catastrophe (atypical mitotic figures) and necrosis of the tumor are both suggestive of the effectiveness at the cellular level of the chemotherapy. Mitotic catastrophe is a cellular process of eliminating eukaryote cells, which are incompetent in proceeding a normal mitosis. This process finally leads to apoptosis, necrosis or senescence in case of cells not being able to repair the DNA or mitochondrial damage. If mitotic catastrophe is enhanced using therapeutic products, it may finally lead to the interruption of tumor growth. DNA-damage induced by platinum analogues is known to result in mitotic catastrophe. Multinucleation is another histopathological sign of mitotic catastrophe (Vitale et al., 2011). The noticed vacuolar to hydropic degeneration in the present case are findings seen with oncosis, which lead to necrosis and cell death (Majno and Joris, 1995).

\section{CONCLUSION}

In this report, a case of SCC is presented where intratumoral administration of carboplatin following surgical excision was used as treatment protocol, after tumor regrowth was seen with the previous treatment. Despite the increase in the tumor size, histopathologi- cal evaluation showed vacuolar to hydropic degeneration. However, further knowledge on the efficacy and safety of carboplatin after systemic and intratumoral administration is lacking in birds. This case report demonstrates that dose extrapolation of chemotherapeutic agents from other animal species does not guarantee success. The observed vacuolar to hydropic degeneration and the presence of mitotic catastrophe following carboplatin treatment are suggestive for the effectiveness at cellular level of the chemotherapy. Therefore, a higher dosage, another administration route or combination with radiation therapy should be considered. Regular blood hematology and biochemistry are recommended in order to follow-up possible side-effects of chemotherapy.

\section{LITERATURE}

Abu J., Wünschmann A., Redig P.T., Feeney D. (2009). Management of a cutaneous SCC in an American flamingo (Phoenicopterus ruber). Journal of Avian Medicine and Surgery 23, 44-48.

Antonissen G., Devreese M., De Baere S., Hellebuyck T., Van de Maele I., Rouffaer L., Stemkens H.J.J., De Backer P., Martel A., Croubels S. (2015). Comparative pharmacokinetics and allometric scaling of carboplatin in different avian species. Plos One 10, e134177.

Carpenter J.W. (2012). Exotic Animal Formulary. Fourth edition, Elsevier, Saunders, Philadelphia, p. 183-438.

Childs-Sanford S.E., Rassnick K.M., Alcaraz A. (2006). Carboplatin for treatment of a Sertoli cell tumor in a mallard (Anas platyrhynchos). Veterinary and Comparative Oncology 4, 51-56.

Dilruba S., Kalayda G.V. (2016). Platinum-based drugs: past, present and future. Cancer Chemotherapeutic Pharmacology 77, 1103-1124.

Ferrell S.T., Marlar A.B., Garner M., Lung N.P. (2006). Intralesional cisplatin chemotherapy and topical cryotherapy for the control of choanal squamous cell carcinoma in an African penguin. Journal of Zoo and Wildlife Medicine 37, 539-541.

Filippich L.J., Bucher A.M., Charles B.G. (2000). Platinum pharmacokinetics in sulphur crested cockatoos (Cacatua galerita) following single-dose cisplatin infusion. Australian Veterinary Journal 78, 406-411.

Filippich L.J. (2004). Tumor control in birds. Seminars in Avian and Exotic Pet Medicine 13, 25-43.

Filippich L.J., Charles B.G. (2004). Current research in avian chemotherapy. Veterinary Clinics of North America: Exotic Animal Practice 7, 821-831.

Filippich L.J., Charles B.G., Sutton R.H., Bucher A.M. (2004). Carboplatin pharmacokinetics following a single-dose infusion in sulphur-crested cockatoos (Cacatua galerita). Australian Veterinary Journal 82, 366-369.

Filippich L.J., Charles B.G., Sutton R.H., Bucher A.M. (2005). Carboplatin administration in sulphur-crested cockatoos (Cacatua galerita): clinical observations. Journal of Avian Medicine and Surgery 19, 92-97.

Friedman A., Meidovsky A., Leitner G., Sklan D. (1991). Decreased resistance and immune response to Escherichia coli infection in chicks with low or high intakes of vitamin A. The Journal of Nutrition 121, 395-400.

Graham J.E., Kent M.S., Théon A. (2004). Current thera- 
pies in exotic animal oncology. Veterinary Clinics of North America: Exotic Animal Practice 7, 757-781.

Hahn K.A. (2005). Chemotherapy dose calculation and administration in exotic animal species. Seminars in Avian and Exotic Pet Medicine 14, 193-198.

Harris D.J. (1997). Therapeutic avian techniques.Seminars in Avian and Exotic Pet Medicine 6, 55-62.

Ito H., Yamaguchi H., Fujikawa A., Shiida N., Tanaka N., Ogura J., Kobayashi M., Yamada T., Mano N., Iseki K. (2013). Quantification of intact carboplatin in human plasma ultrafitrates using hydrophilic interaction liquid chromatography-tandem mass spectrometry and its application to a pharmacokinetic study. Journal of chromatography. B, Analytical Technologies in the Biomedical and Life Sciences 917-918, 18-23.

Kent M.S. (2004). The use of chemotherapy in exotic animals. Veterinary Clinics of North America: Exotic Animal Practice 7, 807-820.

Klaphake E., Beazley-Keane S.L., Jones M., Shoieb A. (2006). Multisite integumentary squamous cell carcinoma in an African grey parrot (Psittacus erithacus erithacus). Veterinary Record 158, 593-596.

Knox, R. J., Friedlos, F., Lydall, D. A., Roberts, J. J. (1986). Mechanism of cytotoxicity of anticancer platinum drugs: evidence that cis-diamminedichloroplatinum (II) and cisdiammine-(1, 1-cyclobutanedicarboxylato) platinum (II) differ only in the kinetics of their interaction with DNA. Cancer Research 46, 1972-1979.

Koski M.A. (2002). Dermatologic diseases in psittacine birds: an investigational approach. Seminars in Avian and Exotic Pet Medicine 11, 105-124.

Le K., Nevarez J. (2011). What is your diagnosis. Journal of Avian Medicine and Surgery 25, 301-303.

Leach M.W. (1992). A survey of neoplasia in pet birds. Seminars in Avian and Exotic Pet Medicine 1, 52-64.

Lightfoot T.L. (2010). Geriatric psittacine medicine. Veterinary Clinics of North America: Exotic Animal Practice 13, 27-49.

Majno G., Joris I. (1995). Apoptosis, oncosis, and necrosis : An overview of cell death. The American Journal of Pathology 146, 3-15.

Malka S., Keirstead N.D., Gancz A.Y., Taylor W.M., Smith D.A. (2005). Ingluvial squamous cell carcinoma in a geriatric cockatiel (Nymphicus hollandicus). Journal of Avian Medicine and Surgery 19, 234-239.

Manucy T.K., Bennett R.A., Greenacre C.B., Roberts R.E., Schumacher J., Deem S.L. (1998). Squamous cell carcinoma of the mandibular beak in a Buffon's Macaw (Ara ambigua). Journal of Avian Medicine and Surgery 12, 158-166.

Mauldin G.N., Shiomitsu K. (2005). Principles and practice of radiation therapy in exotic and avian species. Seminars in Avian and Exotic Pet Medicine 14, 168-174.
Mehler S.J., Bennett R.A. (2004). Surgical oncology of exotic animals. Veterinary Clinics of North America: Exotic Animal Practice 7, 783-805.

Meleo K.A. (1997). Tumors of the skin and associated structures. Veterinary Clinics of North America: Small Animal Practice 27, 73-94.

Mo J., Eggers P.K., Raston C.L., Lim L.Y. (2014). Development and validation of a LC/TOF MS method for the determination of carboplatin and paclitaxel in nanovesicles. Analytical and Bioanalytical Chemistry 406, 2659-2667.

Ratcliff H.L. (1933). Incidence and nature of tumors in captive wild mammals and birds. American Journal of Cancer 17, 116-135.

Reavill D.R. (2004). Tumors of pet birds. Veterinary Clinics of North America: Exotic Animal Practice 7, 537-560.

Reavill D.R., Dorrestein G.M. (2010). Pathology of aging psittacines. Veterinary Clinics of North America: Exotic Animal Practice 13, 135-150.

Robat C.S., Ammersbach M., Christoph M. (2017). Avian oncology - Diseases, diagnostics, and therapeutics. Veterinary Clinics of North America: Exotic Animal Practice 20, 57-86.

Siegfried L.M. (1982). Neoplasms identified in free-flying birds. Avian Diseases 27, 86-99.

Theon A.P., Van Vechten M.K., Madewell B.R. (1996). Intratumoral administration of carboplatin for treatment of squamous cell carcinoma of the nasal planum in cats. American Journal of Veterinary Research 57, 205-210.

Vail D.M., Thamm D.H. (2005). Cytotoxic chemotherapy: new players, new tactics. Journal of the American Animal Hospital Association 41, 209-214.

Vitale I., Galluzzi L., Castedo M., Kroemer G. (2011). Mitotic catastrophe: a mechanism for avoiding genomic instability. Nature Reviews Molecular Cell Biology 12, 385-392.

Wilson H., Graham J., Roberts R., Greenacre C., Ritchie B. (2000). Integumentary neoplasms in psittacine birds: treatment strategies. In: Proceedings Annual Conference Association of Avian Veterinarians, 211-214.

Zhang S.L., Yang S.H., Li B., Xu Y.C., Ma J.H., Xu J.F., Zhang X.G. (2011). An alternate and reversible method for flight restraint of cranes. Zoo Biology 30, 342-348.

Zehnder A., Kent M.S. (2011). Avian neoplasia: current challenges and future directions. In: Proceedings of 32 nd Annual AAV Conference. Seattle, Washington, USA, 2735.

Zehnder A., Swift L, Sundaram A., Speer B., Olsen G., Hawkins M., Paul-Murphy J. (2014). Multi-institutional survey of squamous cell carcinoma in birds. In: Proceedings of $35^{\text {th }}$ Annual AAV Conference. New Orleans, LA, USA, 3 . 